\title{
Soil water extraction by roots and Kc for the coffee crop
}

\author{
Adriana L. da Silva1, Isabeli P. Bruno², Klaus Reichardt', Osny O. S. Bacchi' ${ }^{3}$, \\ Durval Dourado-Neto ${ }^{2}$, José L. Favarin², Flávio M. P. da Costa ${ }^{4}$ \& Luis C. Timm ${ }^{5}$
}

\begin{abstract}
Basic information for a rational soil-water management of the coffee crop is still insufficient, particularly under irrigated conditions. Of great importance for the estimation of water requirements of coffee crops are their root distribuition and evapotranspiration crop coefficients. This study compares soil water extraction by roots of coffee plants of the variety "Catuaí Vermelho" (IAC-44), grown in Piracicaba, SP, Brazil, 3 to 5 years old, with direct measurements of root dry matter, showing a good agreement between both approaches, and confirming that most of the root system is distributed in the top soil layer $(0-0.3 \mathrm{~m})$ and that less than $10 \%$ of the root system reaches depths greater than $1.0 \mathrm{~m}$. Calculated evapotranspiration crop coefficients are in agreement with those found in the literature, with an average of 1.1, independent of shoot dry matter, plant height and leaf area index.
\end{abstract}

Key words: perenial crop, soil water storage, water balance

\section{Extração radicular de água e Kc em cultura de café}

\section{RESUMO}

A informação básica para o manejo racional de água e solo na cultura de café ainda é insuficiente, sobretudo em condições de cultura irrigada. A distribuição radicular e os coeficientes de cultura para evapotranspiração são de grande importância para a estimativa da necessidade de água na cultura café. Este estudo compara a extração radicular de água de plantas de café, variedade "Catuaí Vermelho" (IAC-44), cultivado em Piracicaba, SP, Brasil, de 3 a 5 anos de idade, com medidas diretas de material seca de raiz, mostrando boa relação entre as metodologias e confirmando que a maioria do sistema radicular está distribuída na camada superficial de solo $(0-0,3 \mathrm{~m})$ e que menos de $10 \%$ do sistema radicular atingem profundidades maiores que $1,0 \mathrm{~m}$. Os coeficientes de cultura medidos estão de acordo com aqueles encontrados na literatura, com média de 1,1, independentemente da matéria seca, altura de planta e índice de área foliar.

Palavras-chave: cultura perene, armazenamento de água no solo, balanço hídrico

${ }^{1}$ CTC - Fazenda Santo Antônio, s/n, C.P. 162, CEP 13400-970, Piracicaba, SP. Fone: (19) 3429-8161. E-mail: adriana.lucia.silva@gmail.com

2 ESALQ/USP - C.P. 9, CEP 13418-900, Piracicaba, SP. Fone: (19) 3429-4190. E-mail: ipbruno@cena.usp.br; dourado@esalq.usp.br; jlfavari@esalq.usp.br

3 CENA/USP/ - C.P. 96, CEP 13416-903, Piracicaba, SP. Fone: (19) 3429-4712. E-mail: klaus@cena.usp.br; osny@cena.usp.br

4 IICA - Agrometeorologista/SEAF, Ministério do Desenvolvimento Agrário SBN - Q1, Ed. Pal. Des., S-604, CEP 70057-900, Brasília, DF. E-mail: flavio.costa@mda.gov.br

${ }^{5}$ UFPEL. CEP 96001-970 Pelotas, RS. Fone: (53) 3275-7260. E-mail: Ictimm@ufpel.edu.br 


\section{INTRODUCTION}

Coffee is among the most important crops grown in Brazil and, recently, its cultivation reached areas previously considered not adequate due to their pronounced water deficit, which is corrected by supplementary irrigation. This technology brings lower production risks and allows efficient fertilizer use, improving quantity and quality of the product (Silva, 2002). These facts justify research investments to refine management practices in relation to system sustainability and cost/benefit ratio. Due to these facts any improvement in coffee management practices is welcome. Although the actual state of knowledge of the processes that involve water and nutrient dynamics in coffee crops is well developed, there is still room to generate or improve field practices that lead to a greater sustainability, a greater productivity, and a greater efficiency in the use of the available natural resources.

Camargo \& Camargo (2001) recognize that the coffee crop, being perenial, takes two years to complete its phenologic frutification cycle, composed of six distinct phases, starting in September for most climatological conditions in Brazil: 1), vegetative, from Set. to Mar., exposed to long days; 2), also vegetative, from Apr. to Aug., exposed to short days, when vegetative nodes formed during the $1^{\text {st }}$ phase are induced to become reproductive, representing a period of relative rest for the plant, followed by the maturation of the reproductive nodes; 3 ), flowering being induced by rainfall or irrigation, due to an elevation of the water potential in the floral nodes (hydric shock); 4), fruit filling, from Jan. to Mar.; 5), fruit maturation, from Apr. to Jun.; 6), senescence of productive brances which will no longer be induced to flower. During these phases the crop requires soil water to supply 1,100 to 1,300 mm for evapotranspiration. Therefore, root distributions and shoot architecture are of great importance for a rational water management of the crop. Santinato et al. (1996) present evapotranspiration crop coefficients for several crops grown in the states of Minas Gerais and Bahia (Brazil), related to crop line spacing and crop age. In another study, Cordeiro et al. (1987) apud Rena (1998) observed for 6 year old coffee shrubs, that $90 \%$ of the root system explored the 0-0.5 m soil layer, presenting a large concentration of absorbing roots in the surface layer, probably due to irrigation and fertilizer application practices. Rena (1998) states that, in most Brazilian soils, the coffee plant does not present deep roots, $85 \%$ of them being distributed below plant canopy, mostly near the stem. Martins et al. (2006) concluded that coffee, irrigated with 80 to $100 \%$ of the Class A pan evapotranspiration, presents larger values of root dry matter as compared to non irrigated plants. In relation to evapotranspiration crop coefficients, Arruda et al. (2000), Rena \& Maestri (2000), and Villa Nova et al. (2002) indicate the importance of crop management conditions like plant population, spacing and interrow condition.

This study used field water balance data (Silva et al., 2006; 2007), established during one complete phenologic cycle of the coffee crop, to estimate root distribution and crop coefficients from plant soil water extraction data.

\section{MATERIAL AND METHODS}

A water balance experiment was carried out in Piracicaba, SP, Brazil (22 $2^{\circ} 42^{\prime}$ S, $47^{\circ} 38^{\prime}$ W, $580 \mathrm{~m}$ above sea level) on a Rhodic Kandiudalf, locally called "Nitossolo Vermelho Eutroférrico” (EMBRAPA, 1999), under a “Cwa” climate (Köppen, 1931). A three year old coffee crop (Coffea arabica L.), cultivar "Catuaí Vermelho” (IAC-144) was used to evaluate soil water extraction and evapotranspiration crop coefficients during two years (Sept 01, 2003 to Aug 31, 2005). Plant rows followed contour lines on a $10 \%$ slope with a spacing of $1.75 \mathrm{~m}$ between rows and $0.75 \mathrm{~m}$ between plants. In an area of approximately 0.2 ha, five plots of about 120 plants were selected randomly for water balance establishment, which can be found elsewhere (Silva et al., 2006). The classical water balance equation was used, integrated over 14-day periods $\left(\Delta t=t_{i+14}-t_{i}\right)$ :

$$
\mathrm{P}+\mathrm{I}-\mathrm{ER} \pm \Delta \mathrm{S}_{\mathrm{L}}-\mathrm{RO}-\mathrm{Q}_{\mathrm{L}}=0
$$

in which $\mathrm{P}=$ rainfall $(\mathrm{mm})$; $\mathrm{I}=$ irrigation $(\mathrm{mm})$; ER = actual evapotranspiration $(\mathrm{mm}) ; \Delta \mathrm{S}_{\mathrm{L}}=$ soil water storage changes $(\mathrm{mm})$ in the $\mathrm{z}=0$ to $\mathrm{z}=\mathrm{L}=1.0 \mathrm{~m}$ soil layer; $\mathrm{RO}=$ run-off $(\mathrm{mm})$ and $\mathrm{Q}_{\mathrm{L}}=$ drainage soil water fluxes at the lower soil volume limit, taken as $\mathrm{z}=\mathrm{L}=1.0 \mathrm{~m}$, all during periods $\mathrm{t}_{\mathrm{i}}$ and $t_{i+14}$, $i$ being the time index corresponding to days after beginning (DAB); i = 1 stands for September 1, 2003. From this date onwards, 52 fourteen-day water balances were established (Silva et al., 2006), up to 720 DAB.

\section{Soil water extraction by roots}

In order to estimate the extraction of water by roots (RE) only balances for which $\mathrm{P}, \mathrm{I}, \mathrm{RO}$ and $\mathrm{Q}_{\mathrm{L}}$ were null were selected, so that Eq. 1 is reduced to $\mathrm{ER}=\Delta \mathrm{S}$. Assuming that the evaporation from the soil surface is negligibe in relation to plant transpiration, $\Delta S$ would represent RE. This assumption is acceptable based on the fact that the soil surface was always almost completely covered by dead coffee leaf mulch, and that a good weed control was maintained in the interrows during the whole experimental period. At the end of the experiment, interrows were already shaded by coffee branches, so that the canopy represented a full green cover.

Soil water storage changes $\Delta S$ were calculated from soil water content $\theta\left(\mathrm{z}_{\mathrm{j}}, \mathrm{t}_{\mathrm{i}}\right),\left(\mathrm{m}^{3} \mathrm{~m}^{-3}\right)$ measurements obtained using a neutron probe (Bacchi et al., 2002), set at depths $z_{j}(j$ corresponding to a depth index, $\mathrm{j}=0$ for soil surface, using $\Delta \mathrm{z}=0.2 \mathrm{~m}$ ). The chosen depths for measurements were $\mathrm{j}=1$ for $\mathrm{z}=0.2 ; \mathrm{j}=2$ for $\mathrm{z}=0.4 ; \mathrm{j}=3$ for $\mathrm{z}=0.6$; $\mathrm{j}=4$ for $\mathrm{z}=0.8$ and $\mathrm{j}=5$ for $\mathrm{z}=1.0 \mathrm{~m}$ from the soil surface, made at times $t_{i}$ and $t_{i+14}$. Using the trapezoidal rule, we have:

$$
\Delta \mathrm{S}_{\mathrm{j}=\mathrm{L} ; \mathrm{t}, \mathrm{i}+14)}=\mathrm{S}_{\mathrm{L}, \mathrm{i}+14}-\mathrm{S}_{\mathrm{L}, \mathrm{i}}=\left(\bar{\theta}_{\mathrm{t}+14}-\bar{\theta} \mathrm{ti}\right) \mathrm{L}=\left[\sum_{\mathrm{j}=1}^{5} \theta_{\mathrm{j}, \mathrm{i}+14}-\sum_{\mathrm{j}=1}^{5} \theta_{\mathrm{j}, \mathrm{i}}\right] \frac{\mathrm{L}}{5}
$$

In which $\mathrm{L}$ taken as $1,000 \mathrm{~mm}$ in order to obtain $\Delta \mathrm{S}$ in $\mathrm{mm}$.

To estimate coffee root distribuition, $\Delta \mathrm{S}$ was also estimated by layers for the periods $\Delta \mathrm{t}=\mathrm{t}_{\mathrm{i}+14}-\mathrm{t}_{\mathrm{i}}$. Since neutron probe measurements of $\theta$ are averages of a soil volume 
corresponding to spheres of 0.20 to $0.30 \mathrm{~m}$ diameter (depending on soil water content), it was assumed that each $\mathrm{q}$ measurement represents the average of the following soil layers: $\theta_{\mathrm{j}=1}$ represents the 0-0.3 layer; $\theta_{\mathrm{j}=2}$ the $0.3-0.5$ layer; $\theta_{\mathrm{j}=3}$ the $0.5-0.7$ layer; $\theta_{\mathrm{j}=4}$ the 0.7-0.9 layer; and $\theta_{\mathrm{j}=5}$ the 0.9-1.0 layer. In this way, it is assumed that the $\theta_{\mathrm{j}=1}$ measurement includes the soil surface, which was not measured, and that $\theta_{\mathrm{j}=5}$ corresponds only to the 0.9-1.0 m layer. These averages, multiplied by each respective layer thickness in $\mathrm{mm}$, yield layer soil water storages.

Since the number of balances that attend the restriction $\Delta \mathrm{S}=\mathrm{RE}$ is small, it was decided to also include balances of small values of $\mathrm{P}$, specifically those in which $\mathrm{P}$ would not have reached the depth $\mathrm{z}=0.3 \mathrm{~m}$, the limit of the first layer used in the calculations. When $\mathrm{P}$ is large and reaches depths greater than $\mathrm{z}=0.3 \mathrm{~m}$, it would not be possible to differentiate the water extracted from the $0-0.3 \mathrm{~m}$ layer from that of the 0.3-0.5 layer. To choose these balances, the criterium of $\mathrm{P}<\mathrm{DEF}$ (0-0.3) was used, in which DEF (0-0.3) is the deficit of soil water $(\mathrm{mm})$ in relation to field capacity, determined under field conditions.

\section{Evapotranspiration crop coefficients}

The actual evapotranspiration ER was taken as an unknown in Eq. 1 and estimated from the difference of all other components. The reference evapotranspiration $\left(\mathrm{ET}_{\mathrm{o}}\right)$ of a green grass surface was estimated through the Penman-Monteith model (Pereira et al., 1997) using meteorological data collected by an automated weather station, located about $200 \mathrm{~m}$ from the experimental plots. The crop coefficient $\left(\mathrm{K}_{\mathrm{c}}\right)$ for coffee was calculated by the ratio $\mathrm{ER} / \mathrm{ET}_{\mathrm{o}}$ only for balances in which the soil was close to field capacity, $\mathrm{RO}=0$ and $\mathrm{Q}_{\mathrm{L}}=0$. For these particular balance periods $\mathrm{P}$ was of the same order of magnitude as ER, to assure that there was no restriction of soil water, so that ER could be considered equal to $\mathrm{ET}_{\mathrm{c}}$.

\section{Crop growth and development}

The study also involved growth and development analyses of the coffee plants, sampling every 60 days the aerial part of whole plants to evaluate dry matter, plant height and total leaf area (TLA, $\mathrm{m}^{2}$ ) using an area integrator model LAI - 3000. The foliar area index (LAI) was calculated by the ratio of TLA and the area occupied by one plant $\left(0.75 \times 1.75=1.313 \mathrm{~m}^{2}\right)$. Data were interpolated using a spline curve adjustment, in order to obtain intermediate values for all balances.

The direct measurement of the root system was performed only at the end of each cropping year (366 and 720 DAB), in order to minimize plot disturbance during the experimental period, and was made through auger samplings performed in the same layers as those used to estimate DS changes.

\section{RESULTS AND DISCUSSION}

From the 52 consecutive water balances made over the two year period (2003-2005), only 15 attend the criteria used for the calculation of RE (Table 1). The values of RE, calculated for each soil layer and averaged for each year (Table 2), indicate the importance of the surface layer $(0-0.3 \mathrm{~m})$ in contributing to the total RE. Although the coffee root system development is bound primarily to plant genetic characteristics, other factors can also alter its spatial distribution, like the available water in the soil (Franco \& Inforzato, 1946) and the nutrient availability for the plant (Amaral, 2002 apud Barreto et al., 2006). Irrigation practices may also affect primary and secondary root growth in the different soil layers (Barros et al., 1997). In our case, irrigation was applied only once a year, at the end of the dry winter season, when plants were suffering a severe water deficit and a flower fall could occur, affecting productivity. Therefore, irrigation most likely did not affect root distribution, which is a result of the water regime in Piracicaba.

The contribution of each layer decreases drastically with depth, the value for the last layer (0.9-1.0 m) being very small for both years, showing that the root system did not extend significantly below the 1.0 depth. The high values of the standard deviations (SD) and, consequently of the coefficients of variation $(\mathrm{CV})$, are the result of the temporal variability of the microclimatic conditions of the periods used for their evaluation, which can be appreciated through the values of ER shown in Table 1. In terms of percent (Figure 1), RE data show great

Table 1. Water balances selected for the calculation of root extraction (RE)

\begin{tabular}{ccrcccc}
\hline $\begin{array}{c}\text { Balance } \\
\mathbf{N}^{\mathbf{0}}\end{array}$ & $\mathbf{D A B}$ & \multicolumn{1}{c}{$\mathbf{P}$} & $\mathrm{DEF}(\mathbf{0}-\mathbf{0 . 3})$ & $\mathbf{S}_{\mathrm{Li}}$ & \multicolumn{1}{c}{$\Delta \mathrm{S}$} & ER \\
\cline { 3 - 7 } 2 & $14-28$ & 5.8 & 41.4 & 257.4 & -8.1 & -13.9 \\
5 & $56-70$ & 25.3 & 30.4 & 271.0 & -10.7 & -36.1 \\
15 & $196-210$ & 14.0 & 13.7 & 348.5 & -52.3 & -66.3 \\
21 & $280-294$ & 7.2 & 9.3 & 348.7 & -14.6 & -21.8 \\
22 & $294-308$ & 1.9 & 14.6 & 336.2 & -16.9 & -18.8 \\
25 & $336-350$ & 0.0 & 16.6 & 329.3 & -11.9 & -11.9 \\
27 & $364-378$ & 0.0 & 24.8 & 308.9 & -32.6 & -32.6 \\
28 & $378-392$ & 6.5 & 35.1 & 276.4 & -18.0 & -24.5 \\
34 & $462-476$ & 18.9 & 29.4 & 288.3 & -25.8 & -44.7 \\
40 & $546-560$ & 1.4 & 23.2 & 273.5 & -28.3 & -29.7 \\
43 & $588-602$ & 0.0 & 32.3 & 265.3 & -16.4 & -16.4 \\
45 & $616-630$ & 12.4 & 37.8 & 260.4 & -1.5 & -13.9 \\
49 & $672-686$ & 0.0 & 17.3 & 310.3 & -19.6 & -19.6 \\
50 & $686-700$ & 8.7 & 27.8 & 293.7 & -7.3 & -16.0 \\
51 & $700-714$ & 0.0 & 30.5 & 287.2 & -15.8 & -15.8 \\
\hline
\end{tabular}

$\mathrm{DAB}=$ days after beginning; 14 to $350 \mathrm{DAB}=1^{\text {st }}$ year; 344 to $714=2^{\text {nd }}$ year. $\mathrm{P}=$ rainfall; $\mathrm{DEF}$ $(0-0.3)=$ soil water deficit of the $0-0.3 \mathrm{~m}$ soil layer at the beginning of each balance, $\mathrm{S}_{\mathrm{Li}}=$ initial soil water storage of the $0-1.0 \mathrm{~m}$ layer; $\Delta \mathrm{S}_{\mathrm{L}}=$ change in water storage; $\mathrm{ER}=$ actual evapotranspiration

Table 2. Average values of the extraction of water by roots (RE) with respective standard deviations (SD) and coefficients of variation (CV), as a function of depth

\begin{tabular}{ccccccccc}
\hline & \multicolumn{3}{c}{$\mathbf{1}^{\text {st }}$ year } & & \multicolumn{3}{c}{$2^{\text {nd }}$ year } \\
\cline { 2 - 3 } \cline { 6 - 7 } & $\begin{array}{l}\text { Average } \\
\left(\mathbf{m m ~ d ~}^{-1}\right)\end{array}$ & SD & CV & & $\begin{array}{l}\text { Average } \\
\left(\mathbf{m m ~ d}^{-1}\right)\end{array}$ & SD & CV \\
$\Delta \mathrm{S}_{0-30}$ & -1.25 & 0.96 & -77.44 & & -0.99 & 0.46 & -46.27 \\
$\Delta \mathrm{S}_{30-50}$ & -0.30 & 0.26 & -84.79 & & -0.25 & 0.13 & -52.79 \\
$\Delta \mathrm{S}_{50-70}$ & -0.26 & 0.25 & -97.84 & & -0.21 & 0.12 & -60.16 \\
$\Delta \mathrm{S}_{70-90}$ & -0.16 & 0.21 & -128.54 & & -0.20 & 0.17 & -89.08 \\
$\Delta \mathrm{S}_{90-100}$ & -0.04 & 0.09 & -227.31 & & -0.13 & 0.10 & -80.36 \\
$\Delta \mathrm{S}_{0-100}$ & -2.01 & 1.47 & -73.08 & & -1.76 & 0.75 & -42.58 \\
\hline
\end{tabular}


consistency in relation to year and to the direct root dry mass measurements. On average, the 0-0.3 m layer contributes with $58 \%$ of the total, showing evidence of the importance of this soil layer in the water management of the coffee crop.

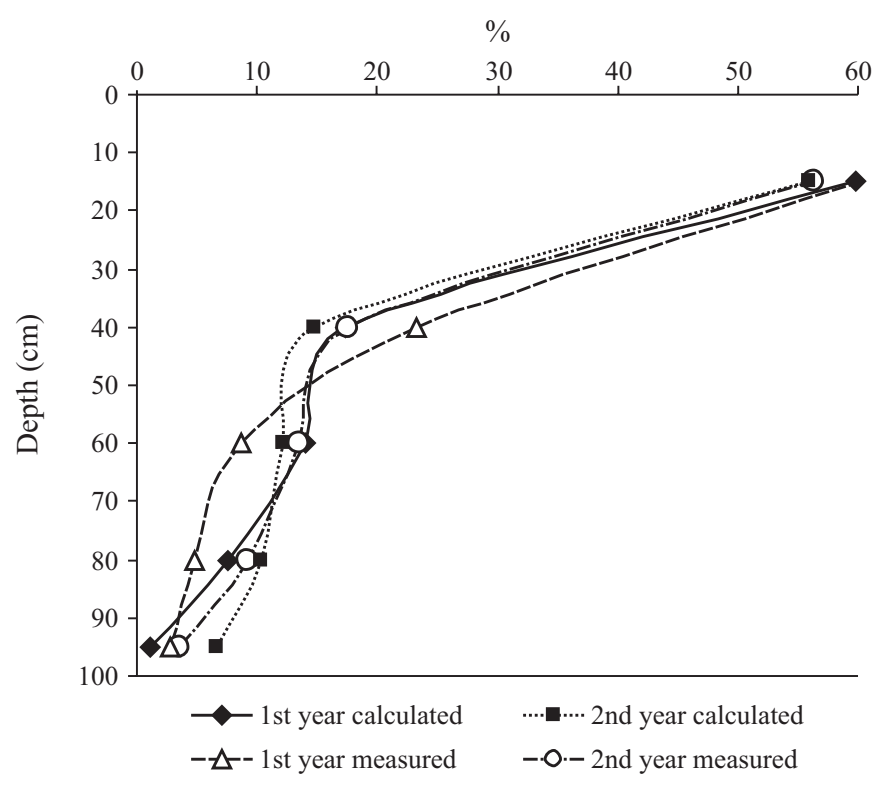

Figure 1. Average $\%$ values of root extraction (RE) of each layer in relation to the total, comparing calculated values through Eq. 2 with field measured values

Table 3. Water balances selected for the calculation of the evapotranspiration crop coefficient $\left(\mathrm{K}_{\mathrm{c}}\right)$ for coffee*

\begin{tabular}{|c|c|c|c|c|c|c|c|c|}
\hline $\begin{array}{c}\text { Balance } \\
\mathbf{N}^{0}\end{array}$ & DAB & $P$ & $\begin{array}{c}\text { ER } \\
(\mathrm{mm})\end{array}$ & $\mathrm{ET}_{0}$ & $K_{c}$ & LAI & $\begin{array}{c}\text { SDM } \\
\mathrm{kg}\end{array}$ & $\begin{array}{c}\mathrm{PH} \\
\mathrm{m}\end{array}$ \\
\hline 6 & $70-84$ & 75.06 & -62.3 & -60.3 & 1.03 & 4.0 & 0.85 & 1.30 \\
\hline 7 & 84-98 & 89.74 & -72.0 & -50.5 & 1.43 & 4.5 & 0.95 & 1.33 \\
\hline 8 & $98-112$ & 49.30 & -57.5 & -62.4 & 0.92 & 5.4 & 1.00 & 1.35 \\
\hline 9 & $112-126$ & 85.60 & -68.1 & -57.5 & 1.18 & 5.6 & 1.07 & 1.36 \\
\hline 10 & $126-140$ & 50.60 & -52.2 & -63.2 & 0.83 & 6.2 & 1.18 & 1.39 \\
\hline 15 & $196-210$ & 14.00 & -62.4 & -55.3 & 1.13 & 9.1 & 1.80 & 1.53 \\
\hline 16 & $210-224$ & 65.20 & -64.2 & -47.7 & 1.35 & 9.4 & 1.88 & 1.57 \\
\hline 17 & 224-238 & 52.30 & -51.7 & -36.1 & 1.43 & 9.6 & 1.95 & 1.60 \\
\hline 18 & $238-252$ & 23.20 & -29.6 & -35.6 & 0.83 & 9.5 & 2.01 & 1.61 \\
\hline 19 & $252-266$ & 25.50 & -25.6 & -24.4 & 1.05 & 9.1 & 2.20 & 1.63 \\
\hline 31 & $420-434$ & 11.80 & -52.2 & -53.9 & 0.97 & 4.0 & 1.70 & 1.81 \\
\hline 32 & $434-448$ & 87.36 & -72.1 & -57.8 & 1.25 & 4.3 & 1.80 & 1.82 \\
\hline 33 & $448-462$ & 32.78 & -73.1 & -64.6 & 1.13 & 4.6 & 1.90 & 1.83 \\
\hline 34 & $462-476$ & 18.88 & -45.1 & -59.9 & 0.75 & 5.0 & 2.05 & 1.85 \\
\hline 35 & $476-490$ & 75.20 & -64.8 & -54.5 & 1.19 & 5.3 & 2.20 & 1.86 \\
\hline 38 & $518-532$ & 30.00 & -88.9 & -71.3 & 1.25 & 8.1 & 3.01 & 1.89 \\
\hline 39 & $532-546$ & 46.50 & -74.5 & -68.2 & 1.09 & 8.5 & 3.15 & 1.91 \\
\hline
\end{tabular}

* DAB - days after beginning; $70 \mathrm{DAB}$ to $266 \mathrm{DAB}-1^{\text {st }}$ year; $420 \mathrm{DAB}$ to $546 \mathrm{DAB}-2^{\text {nd }}$ year; $\mathrm{P}$ - rainfall; ER - actual evapotranspiration; $\mathrm{ET}_{0}$ - Penman-Monteith potencial evapotranspiration; $\mathrm{K}_{\mathrm{c}}$ - crop coefficient for coffe, LAI - foliar area index; SDM - shoot dry matter; PH - plant height

Also, from the 52 consecutive water balances, only 17 could be selected to calculate the evapotranspiration crop coefficients $\mathrm{K}_{\mathrm{c}}$ (Table 3) using the adopted criteria. The variability of the $\mathrm{K}_{\mathrm{c}}$ data oscilated between 0.75 and 1.43, with averages for the $1^{\text {st }}$ year: $1.12 ; \mathrm{SD}=0.23 ; \mathrm{CV}=20.4 \%$, and for the $2^{\text {nd }}$ year: average $=1.09 ; \mathrm{SD}=0.18 ; \mathrm{CV}=16.3 \%$, so that an overall average of $\mathrm{K}_{\mathrm{c}}=1.11 ; \mathrm{SD}=0.20 ; \mathrm{CV}=18.4$, could represent well this coffee variety grown under the experimental conditions. This value is in agreement with others found in the literature, eg Villa Nova et al. (2002), which present a new approach to estimating Kc, taking into account plant population, spacing and interrow condition. They, however, do not indicate number of replicates and estimation errors, so that it is not possible to judge if their Kc values differ for field conditions. They conclude that Kc varies with plant growth, despite the fact that they include leaf area measurements in the Kc calculation. Silva et al. (2006) shows that the variability of all water balance components is of great importance, especially that of ER (in their case with very high coefficients of variation) which lead to a high variability in Kc calculations. Due to the phenologic frutification cycle (Camargo \& Camargo, 2001), the crop invested more in leaf production during the first year, which is reflected in higher values of LAI towards the end of this year (Table 3). It was also observed that the total shoot dry matter (SDM) also had a much higher contribution from leaves during the first year as compared to the second year, during which the higher contribution was due to fruits. The SDM decrease from one year to the other is due to the physiological fall of old leaves and to harvest, during which fruit and some leaves are exported. Although for each year the values of LAI increase consistently, the correspondent Kc values oscilate randomly. Linear regressions between LAI and $\mathrm{K}_{\mathrm{c}}$, and SDM and $\mathrm{K}_{\mathrm{c}}$ presented very low and non-significant regression coefficients, so that $\mathrm{K}_{\mathrm{c}}$ could not be related to the growth of the plants, evaluated through foliar area and shoot dry matter accumulation.

\section{CONCLUSIONS}

1. Coffee plants, variety “Catuaí Vermelho” (IAC-44), 3 to 5 years old, grown in Piracicaba, SP, showed a root distribution that covers mainly the top layer (0-0.3 m) 58\%, with less than $10 \%$ below the $1.0 \mathrm{~m}$ depth.

2. The variability of the evapotranspiration measurements made from field water balances did not allow the observation of the dependence of Kc on plant growth parameters.

3 . An average value of 1.1 , with a coefficient of variation of $18.4 \%$, was obtained.

\section{LITERATURE CITED}

Arruda, F. B.; Iaffe, A.; Sakai, E.; Calheiros, R. O. Resultados anuais do coeficiente de cultura do cafeeiro em um ensaio em Pindorama/SP. In: Simpósio de Pesquisapuda dos Cafés do Brasil, 1, 2000, Poços de Caldas, Anais... Brasília: Embrapa Café/Minasplan, 2000. v.2, p.790-793.

Bacchi, O. O. S.; Reichardt, K.; Calvache, M. Neutron and gamma probes: their use in agronomy. In: Training course series... Vienna: International Atomic Energy Agency, 2002. p.75.

Barros, R. S.; Mota, J. W. da S.; Matta, F. M. da; Maestri, M. Decline of vegetative growth in Coffea arabica L. in relation to leaf temperature, water potential and stomatal conductance. Field Crops Research, v.54, p.65-72, 1997. 
Camargo, A. P.; Camargo, M. B. P. Definição e esquematização das fases fenológicas do cafeeiro arábica nas condições tropicais do Brasil. Bragantia, v.60, n.1, p.65-68, 2001.

EMBRAPA - Empresa Brasileira de Pesquisa Agropecuária. Centro Nacional de Pesquisa de Solo. Sistema brasileiro de classificação de solos. Brasília: Embrapa CNPS, 1999. 412p.

Köppen, W. Grundriss der Klimakunde. Berlin: Walter D. E. Guyter \& Co. 1931. 390p.

Martins, C. C.; Reis, E. F.; Busato, C.; Pezzopane, J. E. M. Crescimento inicial do café Conilon (Coffea canephora Pierre ex Froehner) sob diferentes lâminas de irrigação. Engenharia na Agricultura, v.14, n.3, p.193-201, 2006.

Pereira, A. R.; Villa Nova, N. A.; Sediyama, G. C. Evapo(transpi)ração. Piracicaba: FEALQ, 1997. 183p.

Rena, A. B. A água na fisiologia do cafeeiro. In: Simpósio Estadual do Café, 3, 1998, Vitória. Palestras, painéis e debates... Vitória: CETCAF, 1998. p.132-152.

Rena, A. B; Maestri, M. Relações hídricas no cafeeiro. In: Irrigação e tecnologia moderna. Brasília: ABID, 2000. v.48, p.34-41.
Santinato, R.; Fernandes, A. L. T.; Fernandes, D. R. Irrigação na cultura do café. Campinas: Arbore Agrícola e Comércio, 1996. 146p.

Silva, A. L da. Estudo técnico e econômico do uso do sistema de irrigação por gotejamento na cultura do cafeeiro (Coffea arabica L.). Lavras: UFLA, 2002. 67p. Dissertação Mestrado

Silva, A. L. da; Reichardt, K.; Roveratti, R.; Bacchi, O. O. S.; Timm, L. C.; Oliveira, J. C. M.; Dourado Neto, D. On the use of soil hydraulic conductivity functions in the field. Soil \& Tillage Research, v.93, p.162-170, 2007.

Silva, A. L. da; Roveratti, R.; Reichardt, K.; Bacchi, O. O. S.; Timm, L. C.; Bruno, I. P.; Oliveira, J. C. M.; Dourado Neto, D. Variability of water balance components in a coffee crop grown in Brazil. Scientia Agricola, v.63, p.105-114, 2006.

Villa Nova, N. A.; Favarin, J. L.; Angelocci, L. R.; Dourado Neto, D. Estimativa do coeficiente de cultura do cafeeiro em função de variáveis climatológicas e fitotécnicas. Bragantia, v.61, n.1, p.81-88, 2002. 